Body and Spirit in the Middle Ages 



\section{Body and Spirit in the Middle Ages}

Literature, Philosophy, Medicine

Edited by

Gaia Gubbini

DE GRUYTER 
This book is published in cooperation with the project DramaNet, funded by the European Research Council.

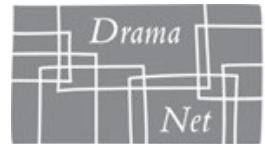

Early Modern European Drama and the Cultural Net

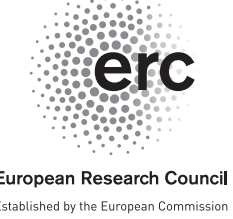

Established by the European Commission

The publication of this book was financially supported by the Alexander von Humboldt Foundation (Germany).

\section{Alexander von Humboldt Stiftung/Foundation}

ISBN 978-3-11-061591-3

e-ISBN (PDF) 978-3-11-061593-7

e-ISBN (EPUB) 978-3-11-061598-2

DOI https://doi.org/10.1515/9783110615937

\section{(c) BY-NC-ND}

This work is licensed under a Creative Commons Attribution-NonCommercial-NoDerivatives 4.0 International License. For details go to http://creativecommons.org/licenses/by-nc-nd/4.0/.

\section{Library of Congress Control Number: 2020931547}

\section{Bibliographic information published by the Deutsche Nationalbibliothek}

The Deutsche Nationalbibliothek lists this publication in the Deutsche Nationalbibliografie; detailed bibliographic data are available on the Internet at http://dnb.dnb.de.

(C) 2020 Gaia Gubbini, published by Walter de Gruyter GmbH, Berlin/Boston.

The book is published with open access at www.degruyter.com.

Cover image: Staatsbibliothek zu Berlin - Preußischer Kulturbesitz, Ms. germ. fol. 282, f. 13r; Design: Melanie Wiener, grafikbuero.berlin Typesetting: Integra Software Services Pvt. Ltd.

Printing and binding: $\mathrm{CPI}$ books $\mathrm{GmbH}$, Leck

www.degruyter.com 